\title{
KAJIAN EFISIENSI BULB-TEE SHAPE AND HALF SLAB GIRDER DENGAN BLISTER TUNGGAL TERHADAP PC-I GIRDER
}

\author{
Edison Leo ${ }^{1}$, Nur Agung M.H. ${ }^{2}$ \\ ${ }^{1}$ Jurusan Teknik Sipil, Universitas Tarumanagara \\ edisonleo41@gmail.com \\ 2 Jurusan Teknik Sipil, Universitas Tarumanagara \\ weichi_93@yahoo.com
}

\begin{abstract}
ABSTRAK
Pada jembatan beton pratekan, kekuatan sebuah struktur jembatan sangat dipengaruhi oleh jenis dan mutu balok gelagar (girder). Pada penelitian ini, penulis merencanakan gelagar sebuah jembatan beton pratekan dengan metode post tension yang menggunakan PC-I girder dan Bulb-Tee Shape and Half Slab (BH) girder dengan blister tunggal sebagai struktur gelagar utamanya. Dasar-dasar perencanaan girder ini mengacu pada Perencanaan Struktur Beton untuk Jembatan (SK.SNI T-12-2004), Pembebanan untuk Jembatan (SK.SNI T-02-2005) dan Bridge Management System (BMS-92). Kabel prategang pada desain girder ini menggunakan kabel jenis Uncoated Stress Relieved Seven Wires Strand ASTM A 416-90a Grade 270 Low Relaxation dengan diameter 0.5 inch (12.70 mm). Analisis beban meliputi analisis beban mati, beban mati tambahan serta beban hidup. Selain itu faktor pengaruh friksi, draw-in dan elastic deformation untuk memperhitungkan kehilangan gaya prategang (prestress losses) jangka pendek (immediate loss) serta faktor pengaruh waktu seperti relaksasi kabel prategang, rangkak beton (creep) dan susut beton (shrinkage) untuk memperhitungkan kehilangan gaya prategang (prestress losses) jangka panjang (time dependent loss). Analisis tegangan menggunakan metode komposit elastis untuk menentukan tegangan yang terjadi pada setiap potongan penampang dengan memperhitungkan gaya prategang efektif yang terjadi. Analisis tegangan komposit elastis dilakukan dengan menggunakan bantuan program spreadsheet yang ditulis penulis.Hasil akhir dari penelitian ini adalah didapat kajian efisiensi I girder dan BH girder dari perbandingan tegangan, volume strand, dan volume beton. Dari penelitian didapatkan kesimpulan dengan tinggi gelagar yang sama, sistem BH girder dengan blister tunggal lebih efisien dari segi tegangan dan volume strand yang diperlukan walaupun volume betonnya lebih besar $6.6 \%$ daripada sistem I girder.
\end{abstract}

Kata kunci: jembatan, post-tension, strand, PC-I girder, BH girder, blister, komposit elastis, tegangan, volume.

\section{PENDAHULUAN}

Perkembangan dunia konstruksi di abad 21, pihak pemilik proyek dan arsitek semakin menginginkan struktur yang semakin tinggi, bentang yang semakin panjang, semakin ringan, semakin kuat tetapi tetap ekonomis dari segi biaya. Sebagai konsekuensi, pihak perencana struktur terus berpacu untuk menghasilkan struktur yang lebih optimal tersebut. Salah satu teknologi konstruksi yang dimanfaatkan untuk mengoptimalkan struktur adalah menggunakan teknologi beton prategang.

Salah satu jenis struktur yang paling sering menggunakan teknologi prategang adalah struktur jembatan beton prategang. Struktur jembatan prategang umumnya dibentuk dari kumpulan balok gelagar (girder) yang disusun secara sejajar beraturan. Adapun jenis -jenis balok gelagar yang sering digunakan pada jembatan-jembatan di Indonesia antara lain : gelagar I (PC-I girder), gelagar U ( $P C$ - $U$ girder), gelagar T ( $P C-T$ girder) dan lain lain.

Pada penelitian ini akan membandingkan salah satu sistem girder prategang yang dinamakan sistem BH girder (Bulb-Tee shape and Half-slab girder) yang telah dikembangkan negara Korea dengan gelagar I (PC-I girder) yang umumnya digunakan di Indonesia. Konsep utama dari sistem BH girder adalah untuk mengurangi jumlah angkur pada ujung balok dan memindahkannya ke intermediate balok pada posisi blister, sehingga dapat mengoptimalkan penggunaan angkur pada daerah tumpuan serta efisiensi dalam penggunaan kabel strand. Skematik dari sistem BH girder dapat dilihat pada Gambar 1. 
Adapun maksud dari penelitian ini adalah untuk membandingkan teknologi $\mathrm{BH}$ girder dengan blister tunggal dengan standar PC-I girder yang umumnya dipakai di Indonesia dari segi tegangan lentur, volume strand dan volume beton yang diperlukan. Analisis mengacu pada kondisi pembebanan yang disesuaikan dengan peraturan pembebanan jembatan Indonesia yaitu SK.SNI T-02-2005 (Pembebanan untuk Jembatan) serta analisis perencanaan mengacu pada peraturan BMS-92 (Bridge Management System) dan SK.SNI T-12-2004 (Perencanaan Struktur Beton untuk Jembatan).

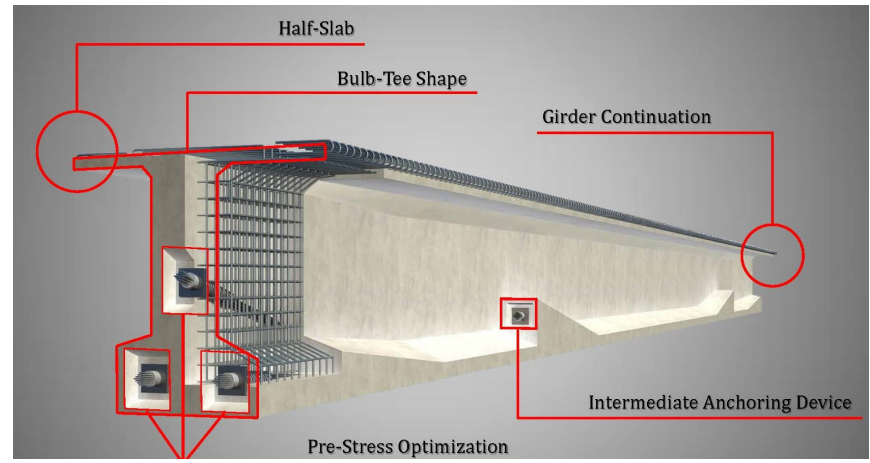

Gambar 1. Skematik BH girder

\section{DASAR TEORI}

Jembatan beton prategang atau sering disebut prestressed concrete bridge merupakan salah satu jenis jembatan dengan material konstruksi beton pratekan atau beton yang berisi kabel baja dengan tujuan untuk memberikan tegangan awal berupa tegangan tekan pada beton. Karena sifat beton yang tidak mampu menahan gaya tarik, dengan memberikan tegangan tekan awal dimaksudkan sebagai solusi untuk mengatasi besarnya tegangan tarik yang timbul pada struktur beton khususnya pada struktur dengan bentang yang besar. Jembatan beton prategang menggunakan sistem girder sebagai komponen balok utamanya.

Konsep perhitungan tegangan yang terjadi pada konstruksi jembatan perlu ditinjau pada 2 kondisi, yaitu kondisi transfer dan kondisi service (layan). Pada kondisi transfer, umumnya gaya prategang yang bekerja pada balok beton hanya memikul berat sendiri gelagar. Gaya prategang yang bekerja pada kondisi transfer adalah gaya prategang yang telah memperhitungkan kehilangan gaya prategang jangka pendek akibat friksi, wedge draw-in dan elastic deformation. Analisis tegangan serat pada potongan penampang menggunakan konsep komposit elastis dengan gaya prategang yang telah diperhitungkan besaran kehilangan gaya prategangnya. Besarnya nilai tegangan pada kondisi transfer dibatasi nilai-nilai berikut :

Batasan tarik serat atas :

$$
-\frac{\text { F-transfer }}{A}+\frac{\text { F-transfer.e. } y_{t}}{I}-\frac{\text { M-transfer. } y_{t}}{I} \leq f_{t i}\left(0.80 \sqrt{f^{\prime}{ }^{\prime}} \mathrm{kg} / \mathrm{cm}^{2}\right)
$$

Batasan tekan serat bawah :

$$
-\frac{\text { F-transfer }}{\mathrm{A}}-\frac{\text { F-transfer.e. } y_{\mathrm{b}}}{\mathrm{I}}+\frac{\text { M-transfer. } \mathrm{y}_{\mathrm{b}}}{\mathrm{I}} \leq \mathrm{f}_{\mathrm{ci}}\left(0.60 \mathrm{f}_{\mathrm{ci}}{ }_{\mathrm{ci}} \mathrm{kg} / \mathrm{cm}^{2}\right)
$$

dengan : F-transfer $=$ gaya transfer, $\mathrm{e}=$ jarak eksentrisitas kabel, $\mathrm{y}_{\mathrm{t}}$ dan $\mathrm{y}_{\mathrm{b}}=$ jarak garis berat penampang, M-transfer $=$ Momen akibat beban luar pada kondisi transfer, $\mathrm{A}=$ Luas penampang, $\mathrm{I}=$ Momen Inersia Penampang, $\mathrm{f}_{\mathrm{ti}}=$ tegangan tarik izin beton, $\mathrm{f}_{\mathrm{ci}}=$ tegangan tekan izin beton, $\mathrm{f}^{\prime}{ }_{\mathrm{ci}}=$ kuat tekan beton pada saat gaya stressing diberikan. 
Pada kondisi service, gaya prategang yang bekerja telah memperhitungkan kehilangan gaya prategang jangka panjang (time dependent losses). Besarnya tegangan yang terjadi pada kondisi service dibatasi nilai-nilai berikut :

Batasan tekan serat atas :

$-\frac{\text { F-service }}{\mathrm{A}}+\frac{\text { F-service.e. } \mathrm{y}_{\mathrm{t}}}{\mathrm{I}}-\frac{\mathrm{M} \text { - } \operatorname{serv}_{1} \cdot \mathrm{y}_{\mathrm{t}}}{\mathrm{I}}-\frac{\mathrm{M}-\mathrm{serv}_{2} \cdot \mathrm{y}_{\mathrm{tc}}}{\mathrm{I}_{\text {composite }}} \leq \mathrm{f}_{\mathrm{c}}\left(0.45 \mathrm{f}_{\mathrm{c}}{ }_{\mathrm{c}} \mathrm{kg} / \mathrm{cm}^{2}\right)$

Batasan tarik serat bawah :

$$
-\frac{\text { F-service }}{\mathrm{A}}-\frac{\text { F-service.e. } \mathrm{y}_{\mathrm{b}}}{\mathrm{I}}+\frac{\mathrm{M} \text { - } \operatorname{serv}_{1} \cdot \mathrm{y}_{\mathrm{b}}}{\mathrm{I}}+\frac{\mathrm{M}-\operatorname{serv}_{2} \cdot \mathrm{y}_{\mathrm{bc}}}{\mathrm{I}_{\text {composite }}} \leq \mathrm{f}_{\mathrm{t}}\left(1.60 \sqrt{\mathrm{f}^{\prime}{ }_{\mathrm{c}}} \mathrm{kg} / \mathrm{cm}^{2}\right)
$$

dengan : F-service = gaya service, $\mathrm{y}_{\mathrm{tc}}$ dan $\mathrm{y}_{\mathrm{bc}}=$ jarak garis berat penampang komposit, $\mathrm{M}$-serv ${ }_{1}$ $=$ Momen akibat beban pada penampang non-komposit, $\mathrm{M}-\operatorname{serv}_{2}=$ Momen akibat beban pada penampang komposit, $\mathrm{I}_{\text {composite }}=$ Momen Inersia Penampang komposit, $\mathrm{f}_{\mathrm{t}}=$ tegangan tarik izin beton, $\mathrm{f}_{\mathrm{c}}=$ tegangan tekan izin beton, $\mathrm{f}_{\mathrm{c}}=$ kuat tekan beton sampel silinder pada umur 28 hari. Untuk tegangan tarik izin pada sambungan tidak diizinkan.

Kehilangan gaya prategang adalah suatu proses dimana gaya prategang awal yang diberikan ke elemen beton mengalami proses reduksi yang progresif selama waktu kurang lebih lima tahun. Dengan demikian, tahapan gaya prategang perlu ditentukan pada setiap tahap pembebanan, dari tahap transfer gaya prategang ke beton, sampai ke tahap prategang memikul beban layan. Pada akhirnya, reduksi gaya prategang dapat dikelompokkan ke dalam dua kategori :

1. Kehilangan gaya prategang yang segera terjadi pada saat proses konstruksi, yakni perpendekan beton secara elastis, kehilangan gaya prategang karena pengangkuran dan kehilangan gaya prategang karena gesekan.

2. Kehilangan gaya prategang yang bergantung pada waktu seperti rangkak, susut dan kehilangan gaya prategang yang diakibatkan karena efek temperatur dan relaksasi baja, yang kesemuanya dapat ditentukan pada kondisi limit tegangan akibat beban kerja di dalam elemen beton prategang.

\section{DATA SPESIFIKASI}

Pada penelitian ini, penulis merencanakan sampel jembatan simple span di atas dua tumpuan sederhana dengan lebar jembatan \pm 9.00 meter. Bentang jembatan yang ditinjau dari bentang $30.60 \mathrm{~m}$ hingga 35.60 meter.

Untuk jembatan dengan gelagar I (PC-I girder) menggunakan 5(lima) buah girder per jembatan dengan tinggi 1.70 meter dengan mutu beton K-500, dengan jarak antar girder (ctc) 1.85 meter, tebal slab $25 \mathrm{~cm}$ dengan mutu beton K-350, tebal deck slab $7 \mathrm{~cm}$, balok diafragma dengan tebal $20 \mathrm{~cm}$ sebanyak 5 no./span. Dari standar Gelagar I di Indonesia, lebar flange atasnya lebih kecil, maka untuk tebal slab dalam pelaksanaan aktual di lapangan berkisar 20 sampai dengan $25 \mathrm{~cm}$ tergantung dari jarak antar girdernya.

Untuk jembatan dengan BH-girder menggunakan 4(empat) buah girder per jembatan dengan tinggi 1.70 meter dengan mutu beton K-500, dengan jarak antar girder (ctc) 2.20 meter, tebal slab $10 \mathrm{~cm}$ dengan mutu beton K-350, balok diafragma dengan tebal $20 \mathrm{~cm}$ sebanyak $5 \mathrm{no} . / \mathrm{span}$. Untuk balok tipe BH girder, desain lebar flange atas didesain sedemikian rupa untuk saling berimpitan antar flange atas setiap gelagar, maka tebal slab yang perlukan tidak setebal tebal slab pada gelagar I. Pada sistem BH girder, slab hanya berfungsi sebagai elemen stuktur yang berfungsi mendistribusikan beban ke gelagar agar lebih merata. 
Dimensi untuk masing-masing tipe gelagar seperti terlihat pada Gambar 2. Adapun dimensidimensi tersebut diambil dari proyek-proyek yang pernah ditangani penulis sebelumnya dengan bekerjasama dengan kontraktor precast girder.
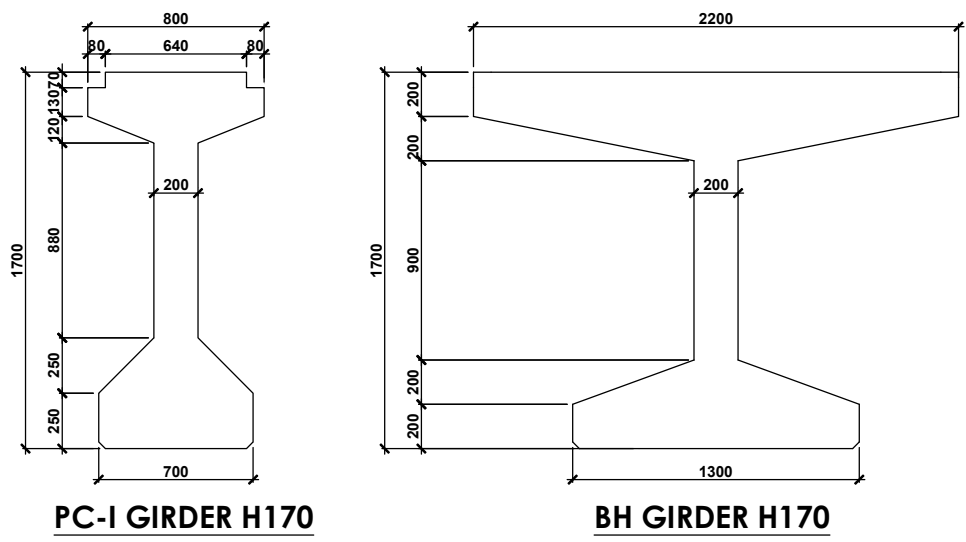

Gambar 2. Dimensi Penampang PC-I dan BH girder tinggi 1.70 meter.

Analisis perencanaan menggunakan tipe balok segmental. Untuk setiap bentang terdiri atas 5 segmen, dengan variasi segmentasi dan mutu beton tertera pada Tabel 1 sebagai berikut :

Tabel 1. Panjang segmentasi girder dan mutu beton

\begin{tabular}{cccc}
\hline $\begin{array}{c}\text { Panjang } \\
\text { Bentang (m) }\end{array}$ & $\begin{array}{c}\text { Jumlah } \\
\text { Segmen }\end{array}$ & Segmentasi (m) & Mutu Beton \\
\hline 30.60 & 5 & $6.3-6.0-6.0-6.0-6.3$ & K-500 \\
\hline 31.60 & 5 & $6.5-6.2-6.2-6.2-6.5$ & K-500 \\
\hline 32.60 & 5 & $6.7-6.4-6.4-6.4-6.7$ & K-500 \\
\hline 33.60 & 5 & $6.9-6.6-6.6-6.6-6.9$ & K-500 \\
\hline 34.60 & 5 & $7.1-6.8-6.8-6.8-7.1$ & K-500 \\
\hline 35.60 & 5 & $7.3-7.0-7.0-7.0-7.3$ & K-500 \\
\hline
\end{tabular}

\section{HASIL ANALISIS}

Dari data-data model dan spesifikasi jembatan di atas, lalu dilakukan perencanaan jembatan dengan menggunakan konsep komposit elastis dengan menggunakan batasan-batasan tegangan dan parameter-parameter yang diuraikan di atas pada bagian dasar teori. Perhitungan dilakukan dengan bantuan program spreadsheet yang disusun penulis, kemudian didapatkan hasil perencanaan untuk masing-masing tipe gelagar sebagai berikut :

Hasil perencanaan konfigurasi kabel prategang untuk PC-I girder seperti yang ditampilkan pada Tabel 2. 
Tabel 2. Konfigurasi Tendon dan Volume Strand PC-I girder.

\begin{tabular}{ccccc}
\hline Panjang & Jumlah & Konfigurasi & \multicolumn{2}{c}{ Volume Strand (kg.) } \\
\cline { 4 - 5 } Bentang (m) & Strand (nos.) & Tendon & Per girder & Per Jembatan \\
\hline 30.60 & 44 & $12+16+16$ & $1,043.46$ & $5,217.30$ \\
\hline 31.60 & 47 & $11+18+18$ & $1,151.03$ & $5,755.15$ \\
\hline 32.60 & 50 & $12+19+19$ & $1,263.25$ & $6,316.25$ \\
\hline 33.60 & 53 & $15+19+19$ & $1,380.12$ & $6,900.60$ \\
\hline 34.60 & 57 & $19+19+19$ & $1,528.46$ & $7,642.28$ \\
\hline 35.60 & 62 & $12+12+19+19$ & $1,710.58$ & $8,552.90$ \\
\hline
\end{tabular}

Hasil perencanaan konfigurasi kabel prategang untuk BH girder seperti yang ditampilkan pada Tabel 3.

Tabel 3. Konfigurasi Tendon dan Volume Strand BH girder.

\begin{tabular}{|c|c|c|c|c|c|c|}
\hline \multirow{2}{*}{$\begin{array}{c}\text { Panjang } \\
\text { Bentang (m) }\end{array}$} & \multirow{2}{*}{$\begin{array}{c}\text { Jarak antar } \\
\text { blister (m) }\end{array}$} & \multicolumn{2}{|c|}{ Jumlah Strand (nos.) } & \multirow{2}{*}{$\begin{array}{c}\text { Konfigurasi } \\
\text { Tendon }\end{array}$} & \multicolumn{2}{|c|}{ Volume Strand (kg.) } \\
\hline & & Utama & Blister & & Per girder & Per Jembatan \\
\hline 30.60 & 14.00 & 37 & 14 & $13+12+12+(7+7)$ & $1,029.36$ & $4,117.42$ \\
\hline 31.60 & 14.60 & 40 & 14 & $12+14+14+(7+7)$ & $1,138.01$ & $4,552.04$ \\
\hline 32.60 & 15.20 & 42 & 14 & $12+15+15+(7+7)$ & $1,226.05$ & $4,904.20$ \\
\hline 33.60 & 15.80 & 44 & 14 & $12+16+16+(7+7)$ & $1,317.19$ & $5,268.76$ \\
\hline 34.60 & 16.40 & 48 & 14 & $10+19+19+(7+7)$ & $1,465.06$ & $5,860.24$ \\
\hline 35.60 & 17.00 & 51 & 14 & $13+19+19+(7+7)$ & $1,591.54$ & $6,366.16$ \\
\hline
\end{tabular}

\section{Perbandingan Volume Beton / Jembatan.}

Perbandingan kebutuhan beton per jembatan dapat dilihat pada Gambar 3 dan Gambar 4. Volume beton telah memperhitungkan kebutuhan beton gelagar dan slab beton diatasnya. Gambar 3 menampilkan kebutuhan beton untuk jembatan PC-I girder dan BH girder, dimana terlihat volume kebutuhan beton jembatan dengan $\mathrm{BH}$ girder lebih besar dibandingkan dengan jembatan PC-I girder.

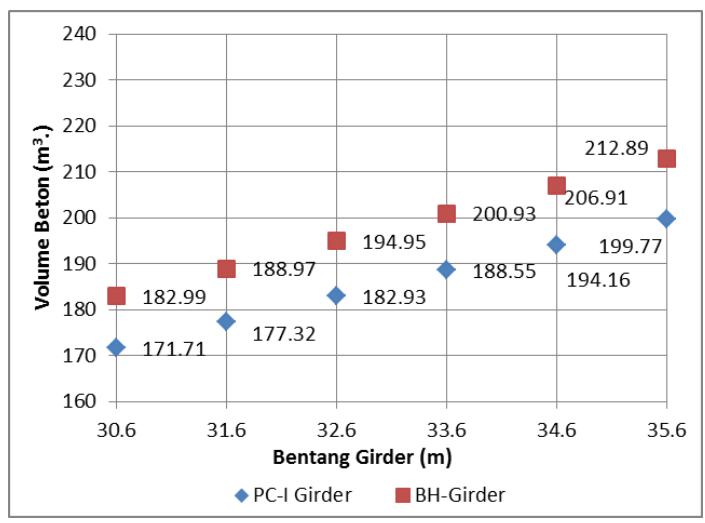

Gambar 3. Grafik perbandingan volume beton tiap jembatan.

Dan Gambar 4 memperlihatkan perbedaan volume beton dalam persentase terhadap volume jembatan PC-I girder, dimana perbedaan persentase tersebut cenderung konstan (tetap) di angka $6.6 \%$. 


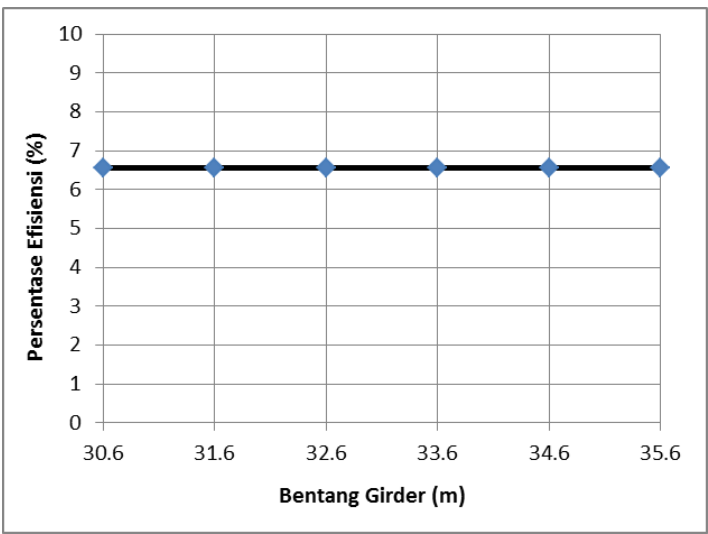

Gambar 4. Grafik persentase inefisiensi volume beton BH girder terhadap PC-I girder

\section{Perbandingan Berat Strand / Jembatan.}

Hasil perhitungan berat strand didapat dari perhitungan jumlah strand dikali berat strand per m' dikali panjang bentang girder pada jembatan dikali banyak girder. Hasil perbandingan berat strand/jembatan antara PC-I girder dan BH girder dapat dilihat pada Gambar. 5 dan Gambar.6. Dimana untuk 1 jembatan PC-I girder terdiri dari 5 buah girder, sedangkan untuk 1 jembatan BH-girder terdiri dari 4 buah girder. Dari Gambar. 5 dapat dilihat bahwa dengan menggunakan tinggi yang sama, efisiensi kebutuhan strand dengan mengunakan sistem BH girder untuk bentang 30.60 meter sampai dengan 35.60 meter berkisar $21 \%$ sampai dengan $25 \%$ atau efisiensinya jika di rata-ratakan sebesar $22.80 \%$.

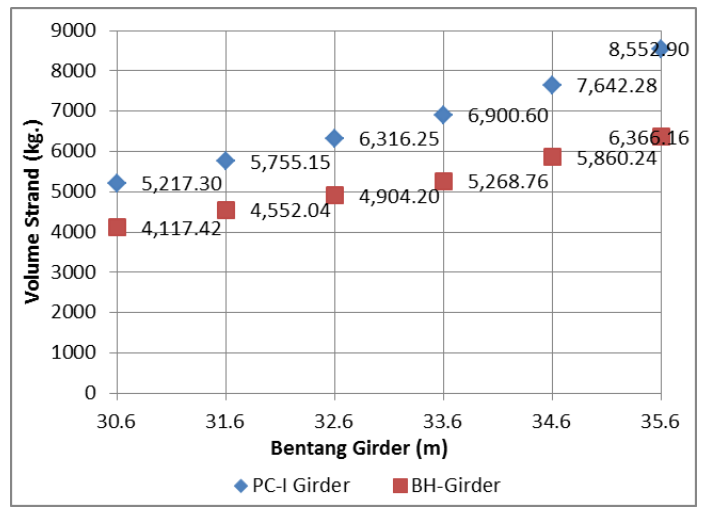

Gambar 5. Grafik perbandingan berat strand tiap jembatan.

Dari Gambar. 6 dapat dilihat bahwa dengan menggunakan tinggi yang sama, efisiensi kebutuhan strand dengan mengunakan sistem $\mathrm{BH}$ girder untuk bentang 30.60 meter sampai dengan 35.60 meter berkisar $21 \%$ sampai dengan $25 \%$ atau efisiensinya jika di rata-ratakan sebesar $22.80 \%$. 


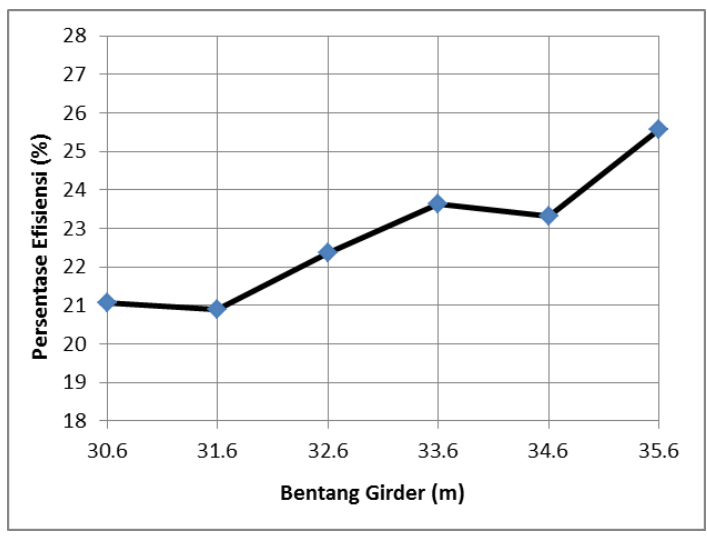

Gambar 6. Grafik persentase efisiensi berat strand BH girder terhadap PC-I girder.

\section{Perhitungan Tegangan Lentur.}

Perhitungan tegangan lentur pada jembatan dilakukan agar dapat diketahui tegangan lentur pada tiap jarak segmental tidak melebihi tegangan izin. Perhitungan tegangan lentur pada jembatan dibagi menjadi tegangan pada kondisi transfer dan tegangan pada kondisi service. Contoh hasil perhitungan tegangan lentur kondisi-kondisi tersebut pada bentang 31.60 meter dapat dilihat pada Gambar 7 sampai dengan Gambar 10.

Pada gambar grafik tegangan sepanjang bentang, garis tegangan serat atas dan serat bawah pada jembatan PC-I girder berbentuk parabola dengan tegangan kritisnya di tengah bentang. Sedangkan garis tegangan serat atas dan serat bawah pada jembatan $\mathrm{BH}$ girder, cenderung konstan (hampir sama) nilainya di sepanjang bentang dan mendekati nilai batasan tegangan izin.

Gambar 7 dan Gambar 8 di bawah menunjukkan tegangan yang terjadi pada serat atas dan serat bawah sepanjang gelagar pada jembatan dengan PC-I girder saat kondisi transfer dan service.

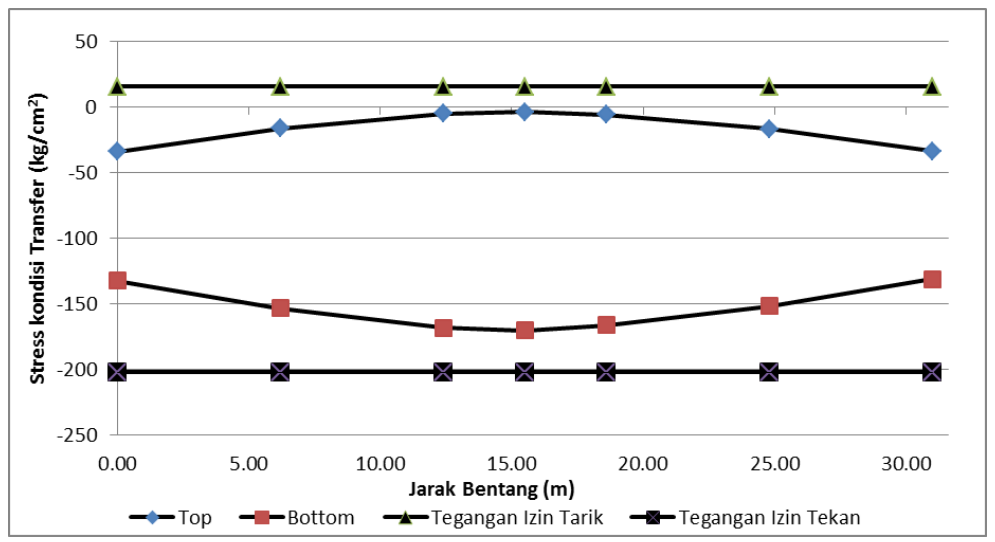

Gambar 7. Grafik tegangan lentur kondisi transfer PC-I girder bentang 31.60 meter. 


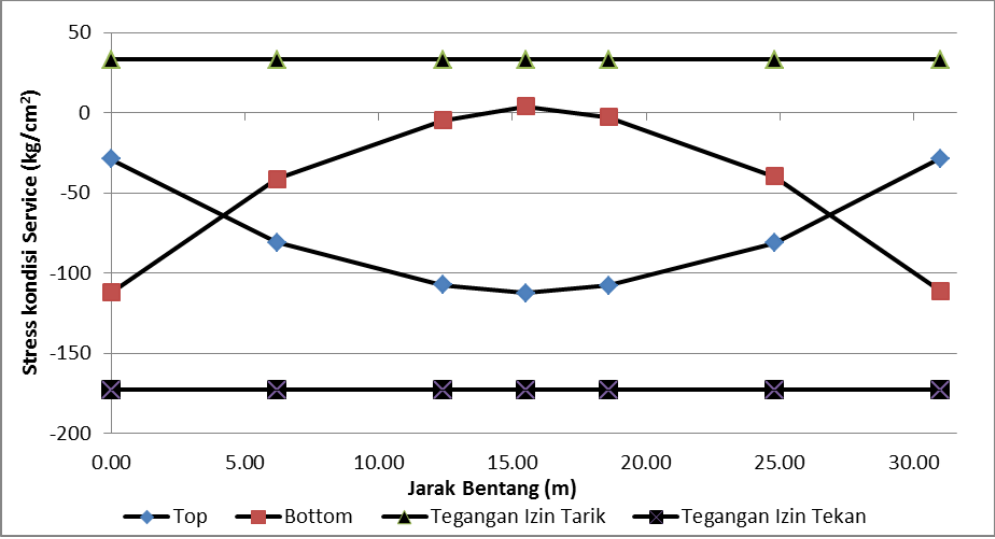

Gambar 8. Grafik tegangan lentur kondisi service PC-I girder bentang 31.60 meter.

Gambar 9 dan Gambar 10 di atas menunjukkan tegangan yang terjadi pada serat atas dan serat bawah sepanjang gelagar pada jembatan dengan $\mathrm{BH}$ girder saat kondisi transfer dan service.

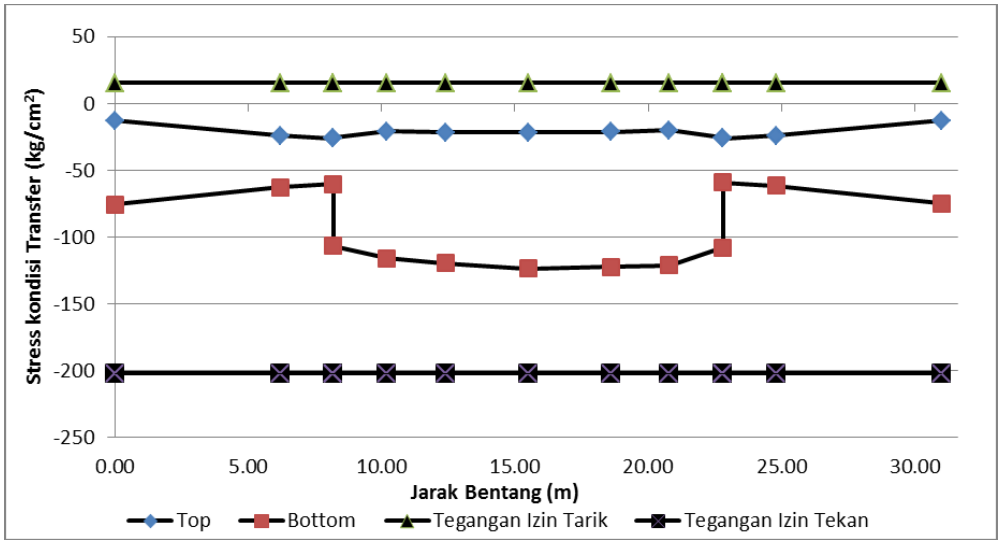

Gambar 9. Grafik tegangan lentur kondisi transfer BH girder bentang 31.60 meter.

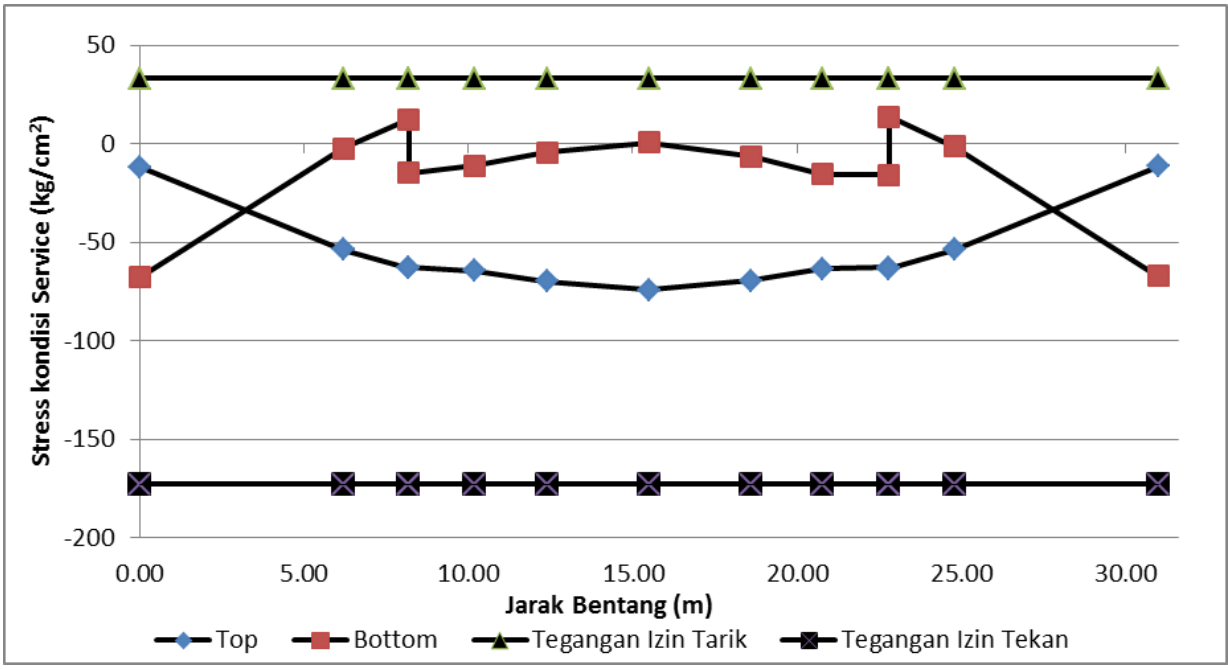

Gambar 10. Grafik tegangan lentur kondisi service BH girder bentang 31.60 meter. 


\section{KESIMPULAN DAN SARAN}

Kesimpulan yang diperoleh dari uraian di atas antara lain :

- Dari hasil perhitungan, volume beton yang diperlukan BH-girder lebih besar dibandingkan volume beton yang diperlukan oleh PC-I girder per jembatan untuk balok gelagar dengan tinggi yang sama. Persentase inefisiensi tersebut cenderung konstan (tetap) untuk bentang girder dari 30,60 meter sampai dengan 35,60 meter.

- Dari hasil perhitungan, berat strand yang diperlukan BH-girder lebih kecil dibandingkan berat strand yang diperlukan oleh PC-I girder per jembatan untuk balok gelagar dengan tinggi yang sama. Persentase efisiensi tersebut cenderung meningkat sebanding dengan bentang girder dari 30,60 meter sampai dengan 35,60 meter.

- Dari grafik perhitungan tegangan lentur dapat dilihat bahwa tegangan pada $\mathrm{BH}$ girder dengan blister tunggal lebih optimal dibandingkan tegangan yang terjadi pada PC-I girder dikarenakan tegangan pada sepanjang bentang $\mathrm{BH}$ girder hampir sama di sepanjang bentang.

- Perlu diteliti lebih lanjut kajian efisiensi BH girder apabila tinggi BH girder dioptimasi serta perbandingan kajian terhadap tipe-tipe gelagar lainnya untuk penelitian-penelitian berikutnya.

\section{REFERENSI}

Aalami, Bijan. O. (2014). Post-Tensioned Buildeings Design and Construction International Edition. ADAPTsoft.com, China.

Badan Standardisasi Nasional (2004). Perencanaan Struktur Beton untuk Jembatan (SK.SNI T12-2004), Badan Standardisasi Nasional, Jakarta.

Badan Standardisasi Nasional (2005). Standar Pembebanan untuk Jembatan (SK.SNI T-022005), Badan Standardisasi Nasional, Jakarta.

Direktorat Jenderal Bina Marga (1992). Bridge Management System (BMS). Peraturan Perencanaan Teknik Jembatan, Departemen Pekerjaan Umum, Jakarta.

Nawy, Edward. G. (2006). Prestressed Concrete A Fundamental Approach $5^{\text {th }}$ ed. Pearson Prentice Hall, New Jersey.

Purboyo, Anton Husen (2013). BH Girder Presentation in Jakarta. Diambil dari : https://www.scribd.com/document/132603787/BH-Girder-Presentation-in-Jakarta\# (diakses 26 April 2013)

Supriyadi, Bambang dan Agus Setyo Muntohar (2000). Jembatan, Universitas Gadjah Mada, Yogyakarta. 